\title{
Persepsi Mahasiswa Terhadap Mutu Tes hasil Belajar Buatan Dosen
}

\author{
Yudha Nata Saputra \\ Universitas Islam Nusantara \\ Email: yudhanata99@gmail.com
}

Tanggal Submitt:06/08/2021 Tanggal diterima:02/12/2021 Tanggal Terbit:30/01/2022

\begin{abstract}
The purpose of this study is to analyze student opinions on the quality of learning outcomes tests made by lecturers. This research is a survey research conducted on 83 students. The criteria for the quality of the learning outcomes tests examined in this study include the compatibility of the tests with the instructional objectives that have been set, the representation of material / learning outcomes in the learning outcomes test prepared by the lecturer, the congruence of the test items with the measured learning outcomes, the suitability of the purpose of using the learning outcomes test, the lectures' ability in making a reliable test and interpreting it to create student activities for learning. The results of the study showed that the quality of the learning outcomes tests made by lecturers obtained an average score of 79.93 which was still included in the medium category. Among the six quality criteria studied, the learning outcomes test criteria made by the lecturer according to their intended use obtained the highest percentage (27.7\%), while the item suitability criteria with the learning outcomes test to be measured obtained the lowest percentage (4.8\%).
\end{abstract}

Keywords: Evaluations, Exam Questions, Learning Achievement, Test Quality.

\begin{abstract}
Abstrak: Tujuan dari penelitian ini, yaitu untuk menganalisa pendapat mahasiswa terhadap mutu tes hasil belajar yang dibuat oleh dosen. Penelitian ini merupakan penelitian survey yang dilakukan kepada 83 mahasiswa. Kriteria mutu tes hasil belajar yang diteliti dalam penelitian ini, meliputi kesesuaian tes hasil belajar yang dibuat dengan tujuan instruksional yang telah ditetapkan, keterwakilan materi/hasil belajar dalam tes hasil belajar yang disusun dosen, kesesuaian itemitem tes hasil belajar dengan hasil belajar yang hendak diukur, kesesuaian tujuan penggunaan tes hasil belajar, kemampuan dosen dalam membuat tes hasil belajar yang reliabel dan menafsirkannya, kemampuan tes hasil belajar yang dibuat untuk membuat aktivitas mahasiswa untuk belajar. Hasil penelitian menunjukkan bahwa mutu tes hasil belajar yang dibuat dosen memperoleh skor rata-rata 79.93 yang masih termasuk dalam kategori sedang. Di antara ke enam kriteria mutu yang diteliti, kriteria tes hasil belajar yang dibuat dosen sesuai dengan tujuan penggunaannya memperoleh presentase tertinggi (27.7\%), sementara kriteria kesesuaian item dengan tes hasil belajar yang hendak diukur memperoleh presentase terendah (4.8\%).
\end{abstract}

Kata Kunci: Evaluasi, Mutu Tes, Prestasi Belajar, Soal Ujian.

\section{Pendahuluan}

Tingkat pengangguran terbuka lulusan Universitas mengalami peningkatan dari 5,18\% pada Agustus 2017 menjadi 5,89\% pada Agustus 2018 ${ }^{1}$. Dengan jumlah angkatan kerja sebanyak 131 juta orang, berarti ada sekitar 7,7 juta orang lulusan Universitas yang menganggur. Hasil studi Willis Towers Watson tentang Talent Management and

${ }^{1}$ Berita Resmi Statistik, Keadaan Ketenagakerjaan Indonesia Agustus 2018, 2018. 
Rewards sejak tahun 2014 mengungkap, delapan dari sepuluh perusahaan di Indonesia kesulitan mendapatkan lulusan perguruan tinggi yang siap pakai

Banyaknya lulusan perguruan tinggi yang menganggur karena tidak siap pakai, menjadi bukti bahwa kurikulum perguruan tinggi belum cukup relevan dalam menghasilan lulusan yang dibutuhkan oleh pasar tenaga kerja. Ketika bicara kurikulum, setidaknya terdapat empat komponen utama yang membentuknya, yaitu tujuan, materi, metode dan evaluasi yang satu sama lain saling terkait. Evaluasi sebagai salah satu komponen kurikulum memegang peranan yang penting dalam menentukan keberhasilan proses belajar mengajar di perguruan tinggi ${ }^{3}$. Hal ini sesuai dengan yang dikatakan oleh Bank Dunia bahwa :"Keluaran pendidikan adalah pencapaian prestasi belajar murid yang meliputi pengetahuan, keterampilan, tingkah laku dan sikap yang diukur dengan test, hasil ujian dan sejenisnya"4. Begitu pentingnya peranan tes dalam kegiatan belajar mengajar maka sudah sepatutnya untuk lebih memberikan perhatian terhadap mutu tes hasil belajar yang dibuat sehingga dapat memberikan informasi untuk dilakukannya kebijakan-kebijakan mutu.

Namun pada kenyataannya, kualitas tes hasil belajar yang disusun oleh dosen masih memiliki kekurangan. Hasil penelitian mengemukakan sekitar 76\% dosen Fakultas Teknik Universitas Negeri Yogyakarta belum menyusun kisi-kisi tes sebagai pedoman dalam penyusunan tes. Belum semua dosen melakukan telaah ulang secara teori terhadap kualitas soal yang sudah dibuat. Dalam pembuatan soal tes uraian, masih terdapat kelemahan dalam aspek pembobotan nilai dan kebebasan memilih soal. Untuk tes objektif, kelemahan ada pada pilihan jawaban yang tidak sama panjang-pendeknya, halaman soal yang terpisah dengan jawaban. Gambar-gambar yang tidak jelas untuk kedua jenis tes di atas. Mengenai bentuk soal yang diujikan, mayoritas berbentuk uraian. Untuk sebagian dosen yang sudah melakukan telaah ulang terhadap kualitas soal, secara positif sudah mengacu kepada kompetensi hasil belajar dengan materi soal ${ }^{5}$. Analisis terhadap soal ujian tengah semester mata kuliah Geometri jurusan pendidikan Matematika UNIPA misalnya menunjukkan bahwa dari 5 butir soal, 3 soal terbilang sulit, 1 soal sedang dan 1 soal lainnya mudah. Meskipun kelima butir soal tersebut valid namun tingkat realibilitas soal ujiannya berada dalam kategori sedang saja ${ }^{6}$. Sementara itu hasil analisis terhadap kualitas soal buatan dosen FTK UIN Ar-Ranniry menunjukkan bahwa dari segi materi soal baik soal pilihan maupun uraian, keduanya sudah berkategori baik $^{7}$, Namun penelitian ini terbatas mengukur mutu soal hanya kepada aspek materi, seperti kesesuaian soal dengan indikator, kesesuaian soal dengan materi yang

2 G Qomara, 'Pengangguran Sarjana', Republika, 2016

$<$ https://www.republika.co.id/berita/jurnalisme-warga/wacana/16/07/10/oa3n72388-pengangguransarjana $>$.

3 Janice Orrell, 'Feedback on Learning Achievement: Rhetoric and Reality', Teaching in Higher Education, 11.4 (2006), 441-56 <https://doi.org/10.1080/13562510600874235>. 2009).

${ }^{4}$ Sedarmayanti, Sumber Daya Manusia Dan Produktivitas Kerja (Bandung: Penerbit Mandar Maju,

5 S Munadi, 'Analisis Validasi Kualitas Soal Tes Hasil Belajar Pada Pelaksanaan Program Pembelajaran', Cakrawala Pendidikan, 30.1 (2011), 145-59.

${ }^{6}$ Nurhasanah and H Ahmad, 'Analisis Soal Ujian Tengah Semester Mata Kuliah Geometri', Jurnal Pendidikan Pepatudzu Media Pendidikan Dan Sosial Kemasyarakatan, 13.1 (2017), 30-42.

137.

${ }^{7}$ E.N Taib, 'Analisis Kualitas Aspek Materi Butir Soal Buatan Dosen', Jurnal Biotik, 2.2 (2014), 77- 
disampaikan. Sementara aspek-aspek mutu soal yang lain, seperti kecocokan bentuk soal dengan tujuan penggunaan, kemampuan soal untuk membuat mahasiswa belajar, belum diteliti. Sehingga perlu dilakukan penelitian terhadap mutu soal yang lebih komprehensif.

Demikian juga dengan dampak tes hasil belajar yang dibuat dosen terhadap perilaku mahasiswa belum memberikan manfaat yang positif, tes yang seharusnya bisa memotivasi mahasiswa untuk belajar malah yang terjadi sebaliknya. Hasil penelitian terhadap tingkat kecemasan dan kejadian insomnia pada mahasiswa keperawatan yang akan melaksanakan ujian akhir semester di Universitas TribhuwanaTunggadewi Malang, hasilnya ada hubungan yang kuat antara tingkat kecemasan dengan kejadian insomnia ${ }^{8}$. Penelitian tentang teknik koping pada mahasiswa ketika mengikuti ujian semester di jurusan Tarbiyah Institut Agama Islam Negeri Raden Intan, menemukan sebesar 64\% mahasiswa berjenis kelamin laki-laki mempunyai teknik koping yang konstruktif, sementara 36\% lainnya destruktif. Delapan puluh persen mahasiswa perempuan memiliki mekanisme koping konstruktif, 20\% destruktif. Hasil analisa menunjukkan tidak ada perbedaan mekanisme koping mahasiswa laki-laki dan perempuan dalam menghadapi ujian semester ". Safitri, menemukan bahwa ada hubungan negatif yang signifikan antara kesabaran dengan stres menghadapi ujian pada mahasiswa Fakultas Psikologi dan Ilmu Sosial Budaya Universitas Islam Indonesia, tingkat kesabaran berpengaruh terhadap penurunan stres sebesar $27 \%{ }^{10}$. Penelitian terhadap perilaku menyontek dengan self efficacy saat ujian pada mahasiswa Universitas Esa Unggul menemukan adanya hubungan negatif yang signifikan ${ }^{11}$.

Sekolah Tinggi Teologi (STT) Cipanas didirikan tahun 1967, adalah STT tertua di provinsi Jawa Barat yang memiliki mahasiswa dari berbagai daerah, terus berupaya untuk meningkatkan mutu pendidikannya, setiap semester diberikan penyebaran kuesioner kepada mahasiswa untuk mengukur kinerja dosen, namun sampai dengan saat ini belum ada pengukuran terhadap mutu soal tes yang dibuat dosen. Akibatnya, tidak diketahui mutu soal maka sulit memberikan umpan balik kepada dosen, sejauhmana pembelajaran yang dilakukan dosen telah mencapai tujuan yang diharapkan. Indikasi dari hal ini bisa dilihat dalam setiap rapat semester, ada mata kuliah yang nilai-nilainya sangat rendah tapi ada juga mata kuliah yang nilainya tinggi-tinggi, tentunya ini menjadi indikasi bahwa ada mata kuliah yang tesnya sangat sulit sebaliknya ada mata kuliah yang tesnya terlampau mudah. Setiap kali kasus-kasus penilaian seperti ini terjadi maka yang kerap disalahkan adalah mahasiswa yang dianggap tidak mampu mengikuti mata kuliah yang bersangkutan. Sulit memberikan masukkan kepada dosen, karena tidak ada fakta-fakta terkait mutu tes hasil belajar yang dibuat dosen. Diharapkan dengan adanya penelitian terhadap mutu tes hasil belajar yang dibuat dosen maka dosen bisa membuat tes yang

8 S.K Yudha, D.K.F Halis, and E Widiani, 'Hubungan Antara Tingkat Kecemasan Dengan Kejadian Insomnia Pada Mahasiswa Yang Akan Menghadapi Ujian Akhir Semester Di Universitas TribhuwanaTunggadewi Malang', Nursing News, 2.1 (2017), 543-54.

9 A Thahir, 'Perbedaan Mekanisme Koping Antara Mahasiswa Laki-Laki Dan Perempuan Dalam Menghadapi Ujian Semester Pada Fakultas Tarbiyah IAIN Raden Intan Lampung', Konseli: Jurnal Bimbingan Dan Konseling, 1.1 (2014), 11-19.

10 A Safitri, 'Hubungan Antara Kesabaran Dengan Stres Menghadapi Ujian Pada Mahasiswa', Jurnal Islamika, 1.1 (2018), 34-40.

${ }^{11}$ M.T Hidayat and Y.A Rozali, 'Hubungan Antara Self Efficacy Dengan Perilaku Menyontek Saat Ujian Pada Mahasiswa Universitas Esa Unggul', Jurnal Psikologi, 13.1 (2015), 1-5. 
bermutu tinggi sehingga mutu prosesdan hasil pembelajaran di STT Cipanas, sebagai STT tertua di Jawa Barat bisa terus ditingkatkan. Berdasarkan permasalahan di atas, maka rumusan masalah dalam penelitian ini, yaitu "Bagaimanakah persepsi mahasiswa terhadap mutu tes hasil belajar yang dibuat dosen ?"

Jadi tujuan dari penelitian terhadap mutu tes hasil belajar ini, yaitu untuk menganalisa pendapat mahasiswa terhadap mutu tes hasil belajar yang dibuat oleh dosen-dosen di STT Cipanas.Penelitian ini berbeda dengan penelitian-penelitian sebelumnya tentang tes hasil belajar, jika selama ini penelitian terhadap tes hasil belajar hanya melihat dari perspektif aktivitas yang dilakukan dosen dalam membuat soal atau menganalisa soal ujian yang sudah dibuat dosen, justru dalam penelitian ini, mahasiswa yang dimintakan umpan baliknya. Sehingga dengan dilakukannya penelitian ini, bisa dikonfirmasi apakah mutu soal tes yang masih kurang mencukupi standar dalam penelitian-penelitian sebelumnya, juga dirasakan oleh mahasiswa sebagai subyek yang mengerjakan tes hasil belajar yang dibuat oleh dosen atau sebaliknya ${ }^{12}$. Umpan balik mahasiswa terhadap soal tes ini sangat penting, hal ini sesuai dengan Pasal 22 Permenristekdikti No. 44 Tahun 2015, tentang Mekanisme Penilaian bahwa mahasiswa perlu diberikan kesempatan dalam memberikan umpan balik dan mempertanyakan hasil penilaian, termasuk keterlibatan dalam prosedur penilaian.

\section{Metode Penelitian}

Metode yang digunakan adalah survey kepada mahasiswa STT Cipanas, Jawa Barat untuk program studi Sarjana. Tujuannya untuk menganalisa persepsi mahasiswa terhadap mutu tes hasil belajar yang dibuat oleh dosen-dosen di STT Cipanas. Sampel dalam penelitian ini sebanyak 83 respoden dari jumlah populasi 104 responden, sampel diambil dengan memakai teknik sampling acak sederhana. Sedangkan ukuran sampel ditentukan dengan menggunakan rumus Slovin. Perhitungan jumlah sampel dapat dilihat di bawah ini:

$$
\begin{aligned}
& n=\frac{N}{1+N(e)^{2}} \\
& n=\frac{104}{1+104(0.05)^{2}} \\
& \boldsymbol{n}=\mathbf{8 2 . 5 4}(\text { dibulatkan menjadi 83) }
\end{aligned}
$$

Keterangan:

$\mathrm{n}=$ ukuran sampel

$\mathrm{N}=$ ukuran populasi

$\mathrm{e}=$ persen kelonggaran ketikdatelitian karena kesalahan pengambilan sampel

Sebelumnya instrumen yang akan disebarkan terlebih dahulu diujicobakan kepada 30 orang responden untuk menguji validitas dan relibilitasnya, dari 35 butir item

${ }^{12}$ Kerri-Ann Kuhn and Sharyn Rundle-Thiele, 'Curriculum Alignment: Student Perception of Learning Achievement Measures', International Journal of Teaching and Learning in Higher Education, 2009 $<$ http://www.isetl.org/ijtlhe/past2.cfm?v=21\&i=3> [accessed 30 November 2021]. 
pernyataan, butir yang valid sebanyak 28 butir. Adapun nilairelibilitasCronbach Alpha sebesar 0,738 menunjukkan relibilitas instrumen penelitian yang tinggi.

Jenis statisitik yang dipakai adalah deskriptif, pedoman skor dapat dilihat pada tabel di bawah:

Tabel 1. Pedoman Skor

\begin{tabular}{|l|c|c|c|c|}
\hline \multicolumn{1}{|c|}{ Penyataan } & SS & S & TS & STS \\
\hline Positif & 4 & 3 & 2 & 1 \\
\hline Negatif & 1 & 2 & 3 & 4 \\
\hline
\end{tabular}

Keterangan:

SS $\quad=$ Sangat Setuju

$\mathrm{S} \quad=$ Setuju

TS $\quad=$ Tidak Setuju

STS = Sangat Tidak Setuju

Skala yang digunakan dalam penelitian ini menggunakan skala Likert, yaitu skala yang digunakan untuk mengukur pendapat, sikap resonden terhadap suatu objek.Item pernyataan dibuat positif dan negatif, agar tidak menggiring responden ke kecenderungan pilihan tertentu.

Setelah jawaban terkumpul maka jawaban dikategorikan ke dalam tiga kategori, yaitu rendah, sedang dan tinggi.

Tabel 2. Rentang Kategori

\begin{tabular}{|c|c|}
\hline Rendah & $\mathrm{X}<\mathrm{M}-1 \mathrm{SD}$ \\
\hline Sedang & $\mathrm{M}-1 \mathrm{SD} \leq \mathrm{X}<\mathrm{M}+1 \mathrm{SD}$ \\
\hline Tinggi & $\mathrm{M}+1 \mathrm{SD} \leq \mathrm{X}$ \\
\hline
\end{tabular}

Sumber: ${ }^{13}$

Keterangan:

$\mathrm{M} \quad=$ Mean

$\mathrm{SD} \quad=$ Standar Deviasi

Untuk mempermudah pengolahan data dalam penelitian ini, maka digunakan sofware SPSS ver. 20.00 .

\section{Pembahasan}

Mutu tes hasil belajar yang dibuat dosen mendapatkan nilai rata-rata 79.93 yang termasuk masih dalam kategori sedang. Sebanyak 12 responden (14.5\%) yang berpendapat bahwa mutu tes hasil belajar yang dibuat dosen rendah, 55 responden (66.3\%) sedang dan 16 responden (19.3\%) berpendapat bahwa mutu tes hasil yang dibuat dosen tinggi.

${ }^{13}$ Saifuddin Azwar, Penyusunan Skala Psikologi (Yogyakarta: Pustaka Pelajar, 2012). 

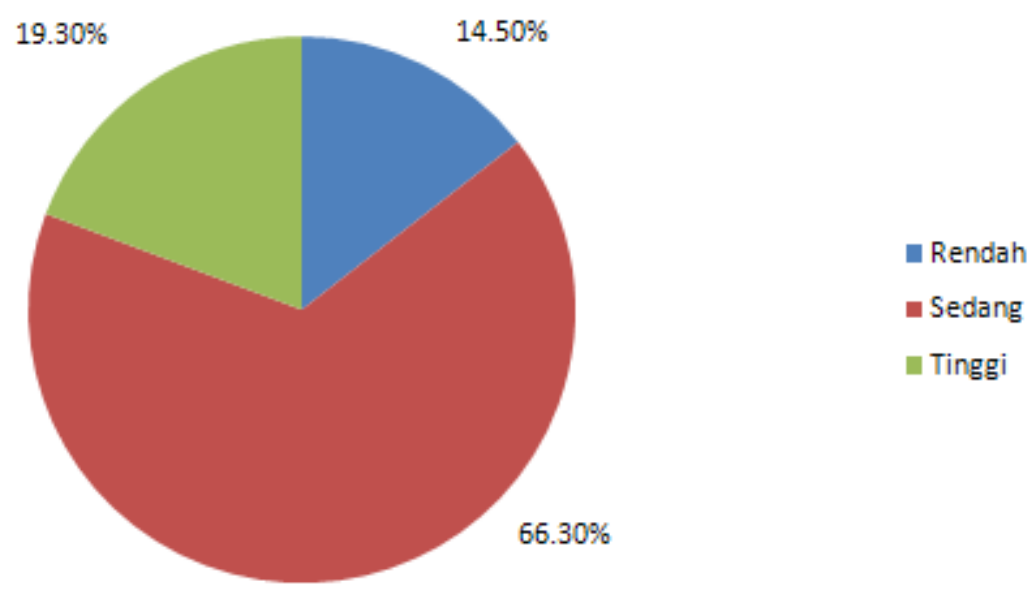

Gambar 1. Mutu Tes Hasil Belajar

Mutu tes hasil belajar yang dibuat oleh dosen di STT Cipanas dengan skor 79.93 masih dalam kategori sedang, menunjukkan mutu tes hasil belajar yang masih memiliki kekurangan. Hasil penelitian ini mendapatkan dukungan dari hasil penelitian terhadap kelemahan dalam soal ujian yang dibuat dosen di Fakultas Teknik Universitas Negeri Yogyakarta ${ }^{14}$.Begitu pula hasil penelitian soal mata kuliah Geometri jurusan Pendidikan Matematika UNIPA dengan temuan mayoritas soal yang terlalu sukar dan reliabilitas soal yang masih berkategori sedang ${ }^{15}$.Masih terdapatnya berbagai kekurangan dari tes yang disusun menunjukkan bahwa kompetensi dosen yang ada masih perlu terus ditingkatkan. Undang-undang No. 14 Tahun 2005 tentang guru dan dosen, menyatakan salah satu kewajiban dosen adalah melakukan kegiatan pengajaran kepada mahasiswa tentunya dalam melaksanakan tugasnya ini, maka dosen selain menyampaikan pengajaran juga perlu memiliki kemampuan dalam melakukan tes kepada mahasiswanya. Pasal 60 ayat 1 (b) dosen wajib "merencanakan, melaksanakan proses pembelajaran, serta menilai dan mengevaluasi hasil pembelajaran ${ }^{16 "}$. Sesuai dengan pernyataan tadi maka kemampuan untuk membuat dan melaksanakan tes hasil belajar merupakan salah satu kompetensi yang penting untuk dimiliki oleh seorang dosen dalam melaksanakan tugasnya.

Mutu tes buatan dosen diukur oleh enam kriteria, yaitu: kesesuaian tes hasil belajar yang dibuat dengan tujuan instruksional yang telah ditetapkan, keterwakilan materi dalam tes yang disusun dosen, kesesuaian item-item tes hasil belajar dengan hasil belajar yang hendak diukur, kesesuaian tujuan penggunaan tes hasil belajar, kemampuan dosen untuk menyusun tes yang reliabel dan menafsirkannya, kemampuan tes dalam membuat aktivitas mahasiswa untuk belajar. Secara rinci, hasil penelitian terhadap kriteria mutu yang diukur dipaparkan sebagai berikut:

\footnotetext{
${ }^{14}$ Munadi.

${ }^{15}$ Nurhasanah and Ahmad.

${ }^{16}$ Indonesia, Undang-Undang Republik Indonesia Nomor 14 Tabun 2005 Tentang Guru Dan Dosen, 2005.
} 


\section{A. Kesesuaian Tes Hasil Belajar Dengan Tujuan Instruksional}

Kesesuaian tes hasil belajar yang dibuat oleh dosen dengan tujuan instruksional memperoleh skor rata-rata sebesar 11.95 berada dalam kategori sedang. Secara rinci, 5 responden $(6 \%)$ berpendapat bahwa kesesuaian tes hasil belajar yang dibuat dosen dengan tujuan instruksional rendah, 60 responden $(72.3 \%)$ sedang dan 18 responden $(21.7 \%)$ berpendapat bahwa kesesuaian tes hasil belajar yang dibuat dosen dengan tujuan instruksional tinggi.

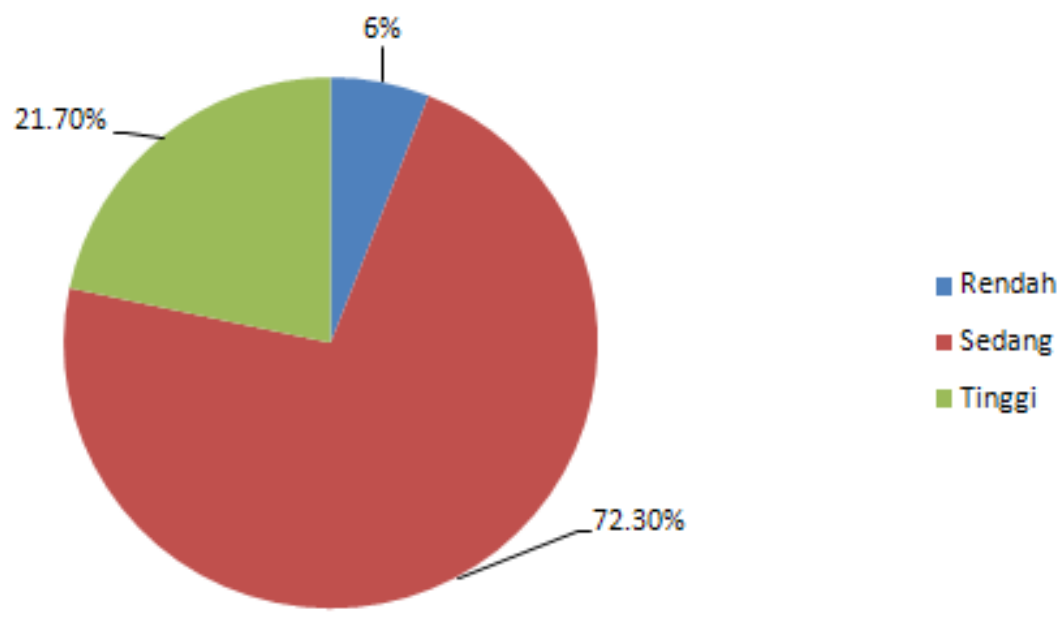

Gambar 2. Kesesuaian Tes Hasil Belajar dengan Tujuan Instruksional

Kesesuaian tes hasil belajar yang dibuat oleh dosen dengan tujuan instruksional yang sudah ditetapkan sebesar 11.95 masih berada dalam kategori sedang artinya belum semua soal disusun mengikuti tujuan instruksional yang sudah ditetapkan.Kondisi ini dapat terjadi jika dosen tidak terlebih dahulu membuat kisi-kisi tes hasil belajar, dalam penyusunan tes hasil belajar.Munadi menemukan bahwa sebanyak " $35.87 \%$ saja yang membuat kisi-kisi soal, 23.92\% tidak membuat kisi-kisi dan 40.21\% tidak jelas apakah membuat kisi-kisi atau tidak "17. Langkah penting dalam penyusunan kisi-kisi tes hasil belajar adalah dengan mengidentifikasi semua tujuan instruksional yang sudah ditetapkan, ketika kisi-kisi soal tidak dibuat maka kemungkinan tes hasil belajar yang dibuat tidak cukup sesuai dengan tujuan instruksional yang sudah ditetapkan, sehingga tidak ada jaminan jika tes hasil belajar dibuat tanpa kisi-kisi akan sesuai dengan tujuan instruksional yang sudah ditetapkan. Jika tes hasil belajar yang dibuat dosen, tidak mengikuti tujuan instruksional yang sudah ditetapkan maka sulit untuk menjamin validitas dan relibilitas tes hasil belajar, sesuai dengan penelitian terhadap "soal ujian tengah semester mata kuliah Geometri Jurusan Matematika UNIPA yang menemukan masih rendahnya validitas dan reliabilitas butir soal yang dibuat dosen " ${ }^{\text {. Melihat }}$ kondisi ini, bisa dikatakan bahwa prinsip edukatif yang tertuang dalam Pasal 20 ayat $2 \mathrm{~b}$ Permenristekdikti No. 44 Tahun 2015 belum tepenuhi, di sana dikatakan bahwa

17 Munadi.

${ }^{18}$ Nurhasanah and Ahmad. 
penilaian yang dilakukan perlu memotivasi mahasiswa ${ }^{19}$ dalam meraih capaian pembelajaran lulusan ${ }^{20}$.

\section{B. Keterwakilan Materi Dalam Tes}

Keterwakilan materi dalam soal memperoleh skor rata-rata 14.24 berada dalam kategori sedang. Dengan rincian, sebanyak 6 responden $(7.2 \%)$ berpendapat bahwa keterwakilan materi dalam soal rendah, 58 responden (69.9\%) sedang dan 19 responden $(22.9 \%)$ berpendapat bahwa keterwakilan materi dalam soal tinggi.

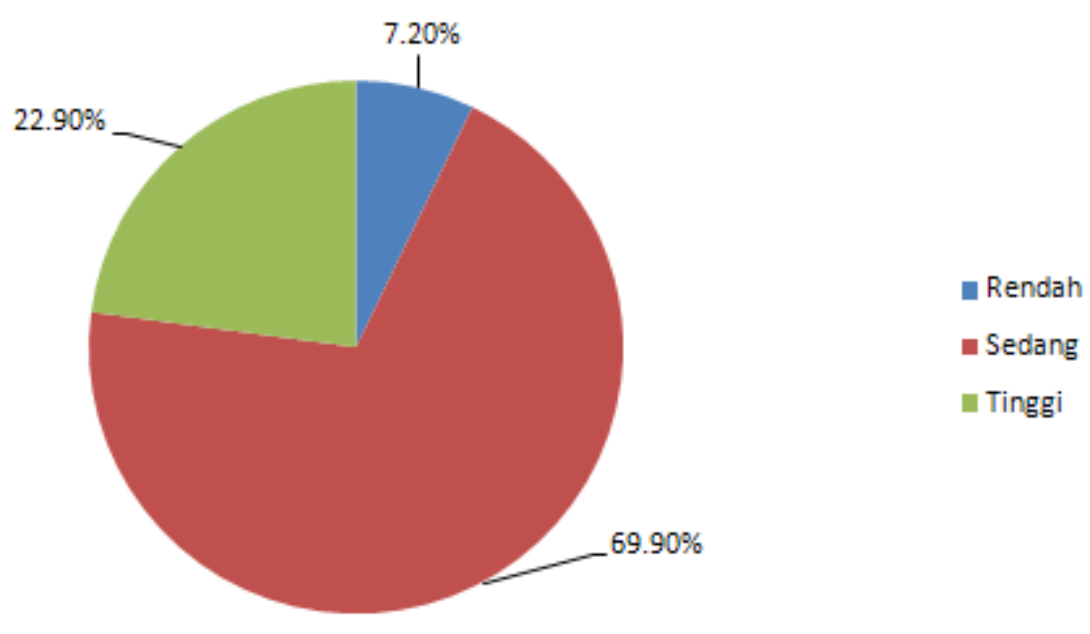

Gambar 3. Keterwakilan materi/hasil belajar dalam tes hasil belajar

Keterwakilan materi/hasil belajar dalam tes sebesar 14.24 yang berada dalam kategori sedang, menunjukkan bahwa tes hasil belajar yang dibuat dosen belum sepenuhnya sesuai dengan materi yang telah disampaikan, hasil belajar yang diharapkan.Jarangnya, dosen di STT Cipanas membuat soal obyektif dibandingkan soal uraian menjadi penyebab keterwakilan materi/hasil belajar yang masih berada dalam kategori sedang.Salah satu keunggulan, tes hasil belajar berbentuk pilihan ganda adalah kemampuannya untuk menampung sejumlah materi yang cukup banyak, karena dalam waktu singkat bisa banyak hal yang hendak ditanyakan namun kelemahannya adalah kurang mampu mengetahui kedalaman penguasaan mahasiswa terhadap bahan yang diujikan.Sebaliknya, tes hasil belajar berbentuk uraian, kemampuan untuk menampung materiyang diujikan terbatas namun mampu mengetahui kedalaman kemampuan mahasiswa terhadap materi yang diujikan karena jumlahnya sedikit.Untuk menutupi kekurangan masing-masing bentuk tes hasil belajar maka kedua bentuk tes hasil belajar perlu dipadukan, kedua-keduanya.Sesuai dengan pendapat Munadi, yang menyarankan agar tes hasil belajar dibuat dengan menggunakan dua tipe tes di atas dengan alasan kebermaknaan ${ }^{21}$. Jarangnya dosen membuat bentuk tes obyektif, bisa terjadi karena membuat tes obyektif membutuhkan waktu yang lama, dan teknik penulisan tes yang lebih sulit dibandingkan tes uraian. Taib mengemukakan beberapa kriteria "tes pilihan ganda yang dibuat dosen, antara lain: kesesuaian soal dengan indikator, pilihan jawaban

${ }^{20}$ Teknologi dan Pendidikan Tinggi Kementerian Riset, Peraturan Menteri Riset, Teknologi, Dan Pendidikan Tinggi Republik Indonesia (Jakarta, 2015).

${ }^{21}$ Munadi. 
harus homogen dan logis, mempunyai satu jawaban yang benar dan pengencoh berfungsi" 22 . Penelitian Munadi menemukan hanya 13,03\% saja dosen yang membuat tes pilihan ganda ${ }^{23}$.

\section{Kesesuaian Item Tes Terhadap Hasil Belajar Yang Hendak Diukur}

Nilai rata-rata jawaban responden terhadap kesesuaian item soal yang dibuat dosen terhadap hasil belajar yang diukur sebesar 8.33 berada dalam kategori sedang. Secara rinci, sebanyak 4 responden (4.8\%) berpendapat bahwa kesesuaian item soal yang dibuat dosen rendah, 67 responden (80.7\%) sedang dan 12 responden (14.5\%) berpendapat bahwa kesesuaian item soal yang dibuat dosen terhadap hasil belajar yang hendak diukur tinggi.

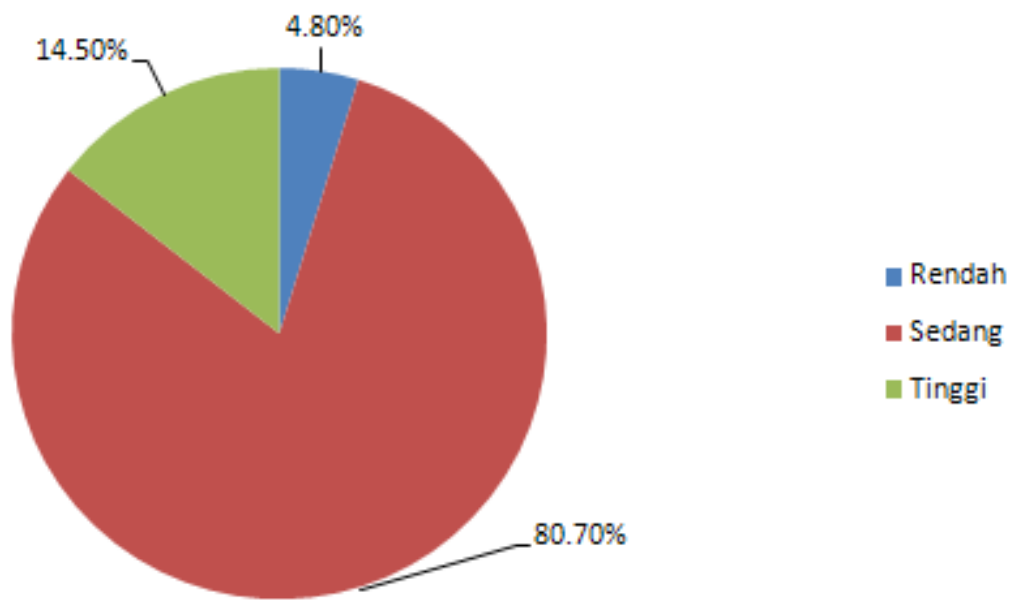

Gambar 4. Kesesuaian item soal terhadap hasil belajar

Kesesuaian item tes hasil belajar yang dibuat dosen dengan hasil belajar yang hendak diukur sebesar 8.33 masih berada dalam kategori sedang. Munadi, menemukan bahwa tes yang dibuat dosen "cenderung mengukur aspek pengetahuan dan pemahaman, belum banyak merambah aspek aplikasi, analisis, sintesis dan evaluasi padahal kecenderungan dosen membuat tes hasil belajar yang berbentuk uraian hampir setengahnya $(55.42 \%)$ ", ${ }^{24}$ artinya tes uraian belum dimanfaatkan secara optimal oleh dosen untuk menggali kedalaman kemampuan mahasiswa terhadap bahan yang diujikan. Melihat kecocokan soal dan tujuan hasil belajar yang masih berada dalam tahap sedang, menunjukkan bahwa item soal tidak sepenuhnya cocok dengan hasil belajar yang diharapkan, bisa saja dalam mata kuliah yang bobot praktikumnya banyak tapi tes hasil belajar dibuat dalam bentuk uraian, atau tes hasil belajar yang seharusnya menuntut kemampuan mahasiswa untuk melakukan evaluasi hanya di ukur sebatas kemampuan mahasiswa dalam memahami. Ketidakcocokan antara item soal dengan tujuan belajar ini, menunjukkan masih perlunya peningkatan keterampilan dosen untuk menyusun soal. Seperti diungkapan di atas, bahwa penyusunan kisi-kisi soal, akan mengurangi risiko ketidakcocokan antara tujuan instruksional, bahan yang disampaikan sampai kepada item

22 Taib.

23 Munadi.

${ }^{24}$ Munadi. 
tes hasil belajar yang cocok dengan tujuan instruksional. Soal yang dibuat tanpa kisi-kisi, akan berisiko kepada mutu tes hasil belajar yang kurang baik, sehingga hasilnya tidak dapat digunakan sebagaimana mestinya. Kecenderungan tes hasil belajar yang bentuknya sama oleh setiap dosen apapun mata kuliahnya, menunjukkan kurangnya usaha dan kreatifitas dosen untuk menyusun soal mengacu kepada tujuan belajar.

\section{Kesesuaian Tujuan Penggunaan Tes Hasil Belajar}

Nilai rata-rata jawaban responden terhadap kesesuaian tujuan penggunaan tes hasil belajar yang dibuat dosen sebesar 13.08 berada dalam kategori sedang. Secara rinci, 12 responden $(14.5 \%)$ responden berpendapat bahwa kesesuaian tujuan penggunaan tes hasil belajar yang dibuat dosen rendah, 48 responden (57.8\%) sedang dan 23 responden $(27.7 \%)$ berpendapat bahwa kesesuaian tujuan penggunaan tes hasil belajar tinggi.

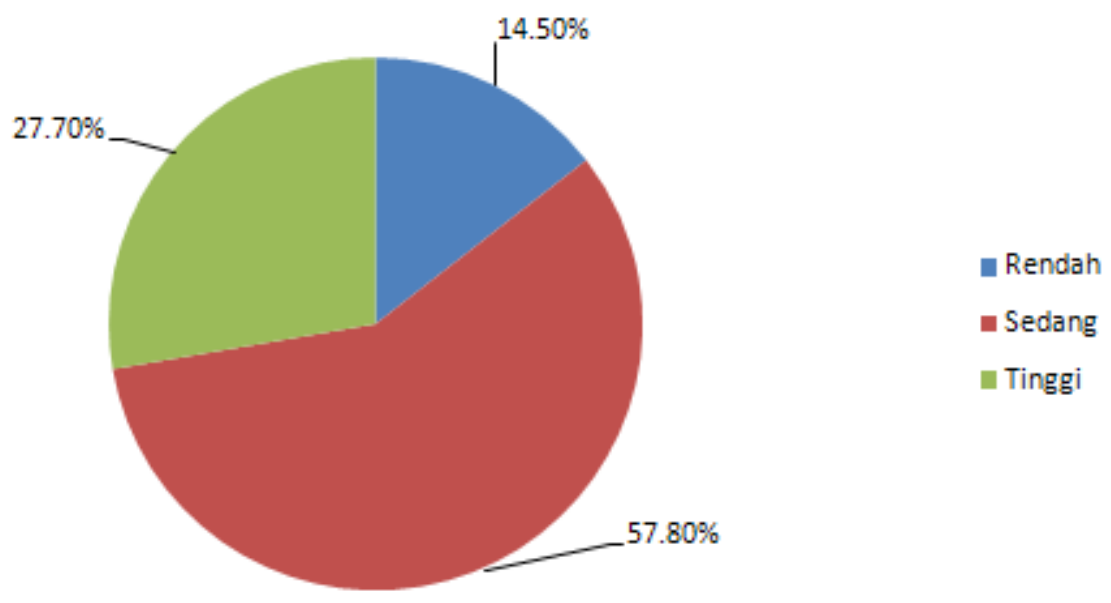

Gambar 5. Kesesuaian tujuan penggunaan tes hasil belajar

Kesesuaian tujuan penggunaan tes hasil belajar sebesar 13.08 berada dalam kategori sedang, artinya tes hasil belajar belum sepenuhnya dipergunakan sebagaimana mestinya. Tes hasil belajar termasuk kedalam tes sumatif, yaitu soal yang digunakan untuk melihat penguasaan mahasiswa dalam menguasai bahan yang hendak disampaikan, seyoganya dengan fungsi tersebut, maka soal yang dibuat harus sebanyak mungkin mengukur penguasaan mahasiswa terhadap bahan dengan tingkat kesukaran yang tidak terlampau sukar, semakin banyak mahasiswa mampu mengerjakan soal tes hasil belajar yang dibuat maka semakin banyak aspek yang dapat diukur, sebaliknya soal tes hasil belajar yang terlalu sukar, akan sulit untuk mengukur aspek mana saja yang sudah dikuasai oleh mahasiswa. Tes hasil belajar, berbeda dengan tes saringan, dimana dalam tes yang bersifat saringan, tingkat kesukaran tes dibuat sangat tinggi, untuk menentukkan siapa yang lolos dan tidak lolos. Kecenderungan, dosen untuk membuat tes hasil belajar yang tingkat kesukarannya tinggi, rupanya ditemukan oleh Nurhasanah dan Ahmad (2017) menemukan bahwa sebagian besar tes hasil belajar yang dibuat dosen memiliki tingkat kesukaran yang tinggi, dari lima butir soal, dua butir soal merupakan soal sangat sukar, satu soal sukar, satu soal sedang dan satu soal mudah. Dalam penyusunan tes hasil belajar yang memiliki fungsi sumatif, maka pendapat Arikunto (2014) yang mengemukakan bahwa soal yang terlalu mudah tidak merangsang 
mahasiswa untuk mengeluarkan segenap kemampuan, sementara soal yang terlalu sukar akan membuat mahasiswa menjadi putus asa,bisa dijadikan pedoman oleh dosen dalam menyusun tes hasil belajar, semakin banyak soal tes yang bisa dikerjakan oleh mahasiswa maka semakin akurat dalam memotret kemampuan mahasiswa dalam menguasai materi yang disampaikan oleh dosen dan sebaliknya. Salah satu prinsip penilaian yang tertuang dalam Permenristekdikti No. 44 Tahun 2015, yaitu prinsip otentik artinya penilaian yang dilakukan harus mencerminkan kemampuan mahasiswa pada saat pembelajaran berlangsung, prinsip ini dapat tercapai jika tujuan penggunaan tes hasil belajar yang dibuat dosen difungsikan sebagai tes sumatif, kesesuaian tujuan penggunaan tes hasil belajar yang masih berada pada kategori sedang, menunjukkan bahwa penilaian yang diperoleh dari tes hasil belajar belum sepenuhnya mencerminkan kemampuan mahasiswa secara utuh sehingga bisa dikatakan bahwa tes hasil belajar yang diberikan belum sepenuhnya memenuhi prinsip otentik.

\section{E. Kemampuan Dosen Untuk Menyusun Tes Secara Reliabel \& Menafsirkannya}

Nilai rata-rata jawaban responden terhadap kemampuan dosen untuk menyusun tes secara reliabel \& menafsirkannya sebesar 14.53 berada dalam kategori sedang. Secara rinci, 14 responden $(16.9 \%)$ berpendapat bahwa kemampuan dosen untuk menyusun tes secara reliabel \& menafsirkannya rendah, 57 responden (68.7\%) sedang dan 12 responden $(14.5 \%)$ berpendapat bahwa kemampuan dosen untuk menyusun tes secara reliabel \& menafsirkannya tinggi.

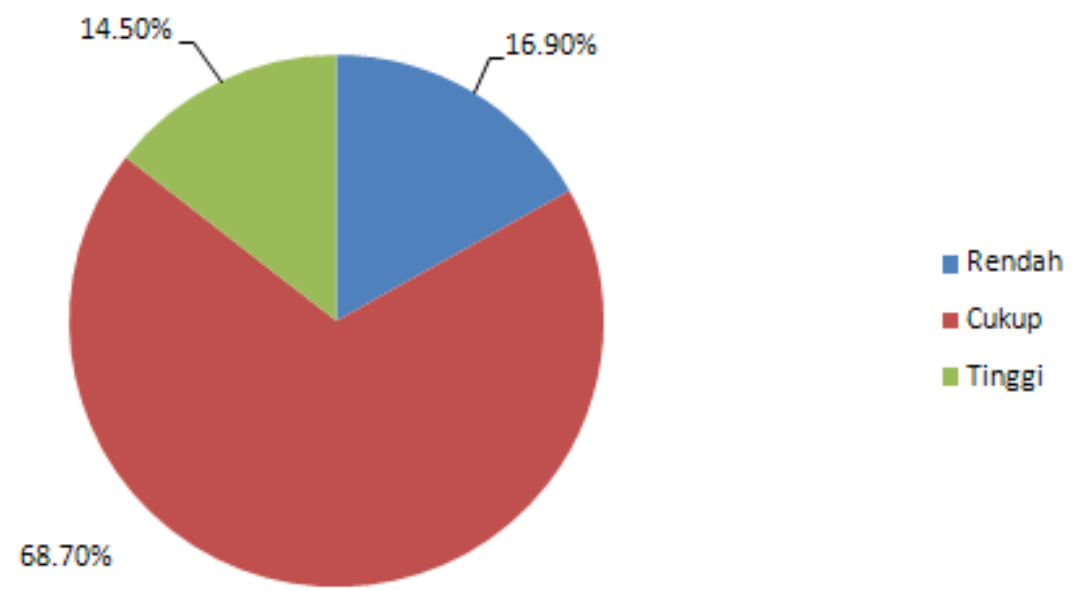

Gambar 6. Kemampuan dosen untuk menyusun tes secara reliabel \& menafsirkannya

Kemampuan dosen untuk menyusun tes secara reliabel \& menafsirkannya sebesar 14.53 berada dalam kategori sedang, kriteria ini berkaitan dengan penilaian mahasiswa terhadap hasil ujian, sejauhmana mahasiswa mempercayai bahwa hasil ujian menggambarkan kemampuan yang dimiliki oleh dirinya. Jika dicermati penelitian yang dilakukan Nurhasanah dan Ahmad (2017) yang mengungkapkan bahwa dengan tingkat kesukaran soal yang mayoritas tinggi, mengakibatkan reliabilitas soal yang sedang dan validitas yang rendah, menjadi suatu indikasi bahwa mahasiswa yang mengerjakan tes hasil belajar yang diberikan, tidak terlampau yakin apakah hasil tes yang diterima 
menggambarkan kemampuan dirinya. Kemampuan dosen untuk menyusun tes secara reliabel \& menafsirkannya kompetensi mahasiswa berkaitan dengan kredibilitas suatu tes bisa memberikan feedback kepada mahasiswa tentang kemampuannya sehingga akan dijadikan bahan evaluasi bagi mahasiswa untuk memperbaiki kekurangannya, yang akan memotivasinya untuk meningkatkan kegiatan belajar sebaliknya kredibilitas tes yang rendah tidak akan membuat mahasiswa untuk memperbaiki kelemahannya apalagi meningkatkan motivasinya untuk belajar. Salah satu aspek dalam prinsip edukatif, yang tertuang dalam Permenristekdikti No. 44 Tahun 2015 adalah "penilaian yang mampu memotivasi mahasiswa untuk memperbaiki perencanaan dan cara belajar," hal ini dapat terlaksana jika kredibilitas tes tinggi, kredibilitas tes yang rendah tidak akan memperbaiki perencanaan dan cara belajar mahasiswa, sebaliknya akan berdampak kepada menurunnya motivasi mahasiswa untuk belajar.

\section{F. Kemampuan Tes Hasil Belajar Untuk Membuat Mahasiswa Belajar}

Nilai rata-rata jawaban responden terhadap kemampuan tes hasil belajar untuk membuat mahasiswa belajar sebesar 17.793 berada dalam kategori sedang. Secara rinci, 14 responden $(16.9 \%)$ berpendapat bahwa kemampuan tes hasil belajar untuk membuat mahasiswa belajar rendah, 49 responden (59\%) sedang dan 20 responden (24.1\%) berpendapat bahwa kemampuan tes hasil belajar untuk membuat mahasiswa belajar tinggi.

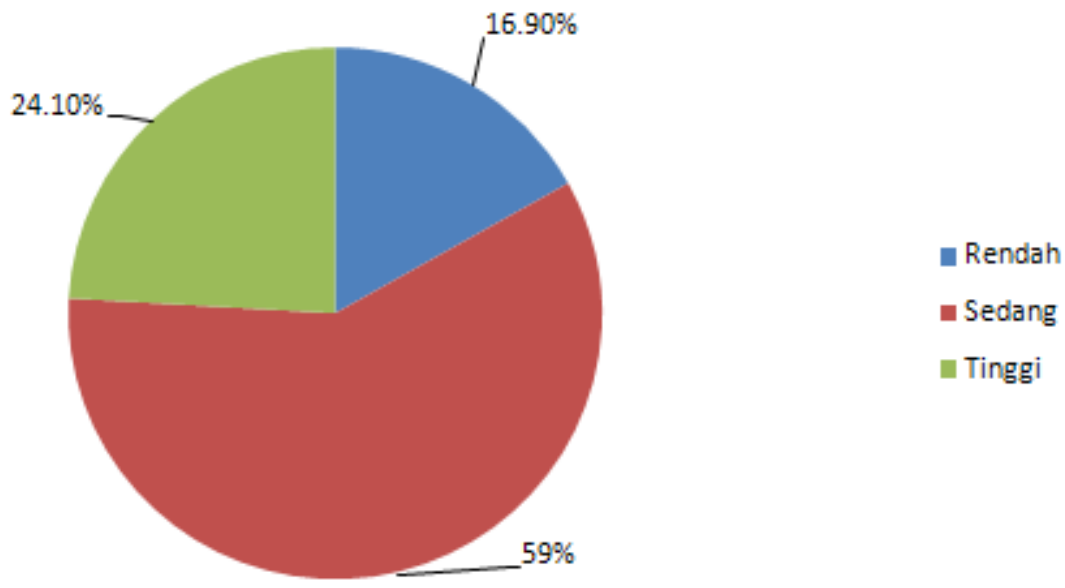

Gambar 7. Kemampuan tes hasil belajar untuk membuat mahasiswa belajar

Kemampuan tes hasil belajar untuk membuat mahasiswa belajar sebesar 17.793 berada dalam kategori sedang, artinya tes hasil belajar yang dibuat dosen belum sepenuhnya mampu meningkatkan motivasi belajar siswa. Ebel sebagaimana dikutip Azwar mengungkapkan "tes hasil belajar sebagai salah satu motivator ekstrinsik yang membuat mahasiswa melakukan kegiatan belajar yang sama pentingnya dengan motivator intrinsik." 25 Tes hasil belajar yang bermutu, akan mampu mendorong mahasiswa untuk melakukan kegiatan belajar, ${ }^{26}$ dan sebaliknya tes hasil belajar yang tidak

\footnotetext{
${ }^{25}$ Saifuddin Azwar, Test Prestasi Fungsi Dan Pengembangan Pengukuran Prestasi Belajar (Yogyakarta: Pustaka Pelajar, 2012).
} 
bermutu akan membuat mahasiswa menghindari tes hasil belajar. Temuan penelitian terhadap kemampuan tes hasil belajar untuk membuat mahasiswa belajar sebesar 17.793 yang berada dalam kategori sedang, menunjukkan bahwa tes hasil belajar belum sepenuhnya membuat mahasiswa termotivasi dalam kegiatan belajar untuk menghadapi tes.Kenyataan ini didukung oleh beberapa hasil penelitian, yang justru menemukan tes hasil belajar yang memberikan efek negatif, jauh dari harapan semula untuk memotivasi mahasiswa untuk belajar.Yudha, et al. melakukan penelitian terhadap tingkat kecemasan dan kejadian insomnia pada mahasiswa keperawatan yang akan melaksanakan ujian akhir semester di Universitas Tribhuwana'Tunggadewi Malang, hasilnya ada hubungan yang kuat antara tingkat kecemasan dengan kejadian insomnia. ${ }^{27}$ Thahir melakukan penelitian tentang teknik koping pada mahasiswa ketika mengikuti ujian di jurusan Tarbiyah Institut Agama Islam Negeri Raden Intan. Hasilnya 64\% laki-laki memiliki teknik koping konstruktif, 36\% destruktif.Delapan puluh persen mahasiswa perempuan memiliki mekanisme koping konstruktif, 20\% destruktif.Hasil analisa menunjukkan baik laki-laki maupun perempuan memiliki teknik koping yang sama saat menghadapi ujian. ${ }^{28}$ Safitri, menemukan "bahwa ada hubungan negatif yang signifikan antara kesabaran dengan stres menghadapi ujian pada mahasiswa Fakultas Psikologi dan Ilmu Sosial Budaya Universitas Islam Indonesia," 29 kesabaran berpengaruh terhadap penurunan stres sebesar 27\%.Hidayat \& Rozali, menemukan korelasi negatif yang signifikan self efficacy dan perilaku menyontek saat ujian. ${ }^{30}$ Berdasarkan beberapa temuan dalam penelitian maka bisa dikatakan tes yang diberikan belum sepenuhnya mampu memotivasi mahasiswa untuk melakukan kegiatan belajar, artinya prinsip penilaian yang edukatif dalam Pasal 20 ayat 2 Permeristekdikti No. 44 Tahun 2015 belum terpenuhi.

\section{Catatan Akhir}

Mutu tes hasil belajar yang dibuat dosen mendapat nilai rata-rata 79.93 masih dalam kelompok sedang. Kriteria mutu tes yang diungkap, meliputi kesesuaian tes dengan tujuan instruksional yang telah ditetapkan, keterwakilan materi dalam tes buatan dosen, kesesuaian item-item soal dengan tujuan belajar, kesesuaian tujuan penggunaan tes, kemampuan dosen untuk menyusun tes secara reliabel dan menafsirkannya, kemampuan tes dalam membuat aktivitas mahasiswa untuk belajar. Di antara ke enam kriteria mutu yang diteliti, kriteria tes cocok dengan tujuan penggunaannya memperoleh presentase tertinggi $(27.7 \%$ ), sementara kriteria kesesuaian item dengan tes hasil belajar yang hendak diukur memperoleh presentase terendah (4.8\%). Supaya mutu tes meningkat sehingga dapat sesuai dengan standar penilaian perguruan tinggi, seperti yang diharapkan dalam Permenristekdikti No. 44 Tahun 2015 maka, maka perlu diadakan pelatihan penyusunan tes hasil belajar kepada dosen dengan melibatkan institusi dan pihak kementerian terkait.

\footnotetext{
${ }^{27}$ Yudha, Halis, and Widiani.

28 Thahir.

29 Safitri.

${ }^{30}$ Hidayat and Rozali.
} 


\section{Daftar Rujukan}

Asvio, Nova, Arpinus, and Suharmon, 'The Influence of Learning Motivation and Learning Environment on Undergraduate Studentsâ $€^{\mathrm{TM}}$ Learning Achievement of Management of Islamic Education, Study Program of Iain Batusangkar In 2016', Noble International Journal of Social Sciences Research, 2.2 (2017), 16-31 $<$ https://ideas.repec.org/a/nap/nijssr/2017p16-31.html> [accessed 30 November 2021]

Azwar, Saifuddin, Penyusunan Skala Psikologi (Yogyakarta: Pustaka Pelajar, 2012)

—, Test Prestasi Fungsi Dan Pengembangan Pengukuran Prestasi Belajar (Yogyakarta: Pustaka Pelajar, 2012)

Berita Resmi Statistik, Keadaan Ketenagakerjaan Indonesia Agustus 2018, 2018

Cheng, Gary, and Juliana Chau, 'Exploring the Relationships between Learning Styles, Online Participation, Learning Achievement and Course Satisfaction: An Empirical Study of a Blended Learning Course', British Journal of Educational Technology, 47.2 (2016), 257-78 < https://doi.org/10.1111/BJET.12243>

Hidayat, M.T, and Y.A Rozali, 'Hubungan Antara Self Efficacy Dengan Perilaku Menyontek Saat Ujian Pada Mahasiswa Universitas Esa Unggul', Jurnal Psikologi, 13.1 (2015), 1-5

Indonesia, Undang-Undang Republik Indonesia Nomor 14 Tahun 2005 Tentang Guru Dan Dosen, 2005

Kementerian Riset, Teknologi dan Pendidikan Tinggi, Peraturan Menteri Riset, Teknologi, Dan Pendidikan Tinggi Republik Indonesia (Jakarta, 2015)

Kuhn, Kerri-Ann, and Sharyn Rundle-Thiele, 'Curriculum Alignment: Student Perception of Learning Achievement Measures', International Journal of Teaching and Leaming in Higher Education, 2009 < http:/ / www.isetl.org/ijtlhe/past2.cfm?v=21\&i=3> [accessed 30 November 2021]

Munadi, S, 'Analisis Validasi Kualitas Soal Tes Hasil Belajar Pada Pelaksanaan Program Pembelajaran', Cakrawala Pendidikan, 30.1 (2011), 145-59

Nurhasanah, and H Ahmad, 'Analisis Soal Ujian Tengah Semester Mata Kuliah Geometri', Jurnal Pendidikan Pepatudzu Media Pendidikan Dan Sosial Kemasyarakatan, 13.1 (2017), 30-42

Orrell, Janice, 'Feedback on Learning Achievement: Rhetoric and Reality', Teaching in HigherEducation, 11.4 (2006), 441-56 < https:/ / doi.org/10.1080/13562510600874235>

Qomara, G, Pengangguran Sarjana', Republike, 2016 <https:/www.republika.co.id/berita/jumalismewarga/wacana/16/07/10/oa3n72388-pengangguran-sarjana $>$

Safitri, A, 'Hubungan Antara Kesabaran Dengan Stres Menghadapi Ujian Pada Mahasiswa', Jurnal Islamika, 1.1 (2018), 34-40

Sedarmayanti, Sumber Daya Manusia Dan Produktivitas Kerja (Bandung: Penerbit Mandar Maju, 2009)

Taib, E.N, 'Analisis Kualitas Aspek Materi Butir Soal Buatan Dosen', Jumal Biotik, 2.2 (2014), 77-137

Thahir, A, 'Perbedaan Mekanisme Koping Antara Mahasiswa Laki-Laki Dan Perempuan Dalam Menghadapi Ujian Semester Pada Fakultas Tarbiyah IAIN Raden Intan Lampung', Konseli: Jurnal Bimbingan Dan Konseling, 1.1 (2014), 11-19

Yudha, S.K, D.K.F Halis, and E Widiani, 'Hubungan Antara Tingkat Kecemasan Dengan Kejadian Insomnia Pada Mahasiswa Yang Akan Menghadapi Ujian Akhir Semester Di Universitas TribhuwanaTunggadewi Malang', Nursing News, 2.1 (2017), 543-54 